Linguista: Jurnal IImiah Bahasa, Sastra, dan Pembelajarannya

Vol. 4, No.1, Juni 2020, hal 9 - 21

ISSN (print): 2579-8944; ISSN (online): 2579-9037

Avaliable online at: http://e-journal.unipma.ac.id/index.php/linguista

\title{
Perempuan Bersampur Merah Karya Intan Andaru: Resiliensi Perempuan Terhadap Stigma dan Trauma
}

\author{
Tania Intan* dan Trisna Gumilar \\ Universitas Padjadjaran, Jl. Raya Bandung-Sumedang Km. 21,7 Jatinangor \\ e-mail: *tania.intan@unpad.ac.id; trisna.gumilar@unpad.ac.id
}

\begin{abstract}
Abstrak
Penelitian ini mengkaji resiliensi protagonis perempuan terhadap stigma dan trauma yang terindikasi di dalam novel berjudul Perempuan Bersampur Merah (2019) karya Intan Andaru terbitan PT. Gramedia Pustaka Utama. Permasalahan dalam novel tersebut dilatari oleh peristiwa pembantaian dukun santet di wilayah Banyuwangi tahun 1998. Penelitian dilakukan dengan metode deskriptif analisis dengan pendekatan psikologi sastra. Data diperoleh melalui teknik simak catat dan dianalisis dengan metode analisis isi. Hasil penelitian menunjukkan bahwa seluruh elemen dari struktur cerita mendukung pada isu yang dibincangkan. Secara keseluruhan, novel Perempuan Bersampur Merah merupakan narasi tentang stigma karena memuat pandanganpandangan negatif yang melekat pada dukun santet, anak dukun santet, penari gandrung, perempuan hamil dan anak yang lahir di luar nikah, perempuan dewasa yang belum menikah, serta keturunan aktivis partai terlarang. Para tokoh perempuan ditampilkan melakukan resiliensi terhadap stigma dan trauma mereka.
\end{abstract}

Kata kunci: resiliensi perempuan, stigma, trauma, dukun santet, Banyuwangi

\section{Perempuan Bersampur Merah by Intan Andaru: Women's Resilience to Stigma and Trauma}

\begin{abstract}
This study examines the female protagonist resilience facing stigma and trauma, which is indicated in a novel titled 'Perempuan Bersampur Merah' (2019) by Intan Andaru published by PT. Gramedia Pustaka Utama. Problems in the novel are motivated by the massacre of the black magician in the Banyuwangi region in 1998. The research was conducted by using a descriptive analysis method, with a psychological psychology approach. Data were obtained by taking note technique and analyzed by using content analysis method. The results show that all elements of the story structure support the issues being discussed. Overall, the novel 'Perempuan Bersampur Merah' is a narrative information about stigma because it contains negative views attached to the existence of black magician, children of black magician, gandrung dancers, pregnant women and children born out of wedlock, unmarried adult woman, and descendants of forbidden party activists. The female protagonists are shown to be resilient to their stigma and trauma.
\end{abstract}

Keywords: female resilience, stigma, trauma, witch, Banyuwangi

\section{Pendahuluan}

Intan Andaru lahir di Banyuwangi pada tanggal 20 Februari 1990. Sebagai dokter yang memiliki hobi menulis, ia mendapat banyak inspirasi saat bertugas di kawasan terpencil di Papua dan Halmahera. Saat berada di Halmahera Selatan, ia 
membuka komunitas Gerakan Suka Membaca (RAK KACA) dan mendirikan perpustakaan umum (Wijayanto, 2019). Pada tahun 2018, Intan Andaru menerima Hibah Perempuan Pekerja Seni Cipta Media Ekspresi. Karya-karya yang telah diterbitkan di antaranya: Namamu dalam Doaku (2015), Teman Hidup (2017), 33 Senja di Halmahera (2017), Kami yang Tersesat pada Seribu Pulau (2018), dan Perempuan Bersampur Merah (2019).

Ketika menulis Perempuan Bersampur Merah, Intan Andaru menggunakan latar tragedi pembantaian dukun santet di wilayah Banyuwangi tahun 1998. la melakukan riset mengenai peristiwa itu dengan mewawancarai keluarga korban. Tokoh utama dalam novelnya, Ayu, kemudian berganti nama menjadi Sari, adalah anak perempuan dari laki-laki yang dituduh dukun santet dan dibantai di hadapan keluarganya. Sari pun berusaha mengungkap dalang pembunuhan terhadap ayah dan korban lainnya.

Pada kenyataannya, peristiwa pembunuhan ini terjadi menjelang kejatuhan rezim Orde Baru tahun 1998, selain kejadian-kejadian anarkis di Jakarta (Setiawan, 2019). Menurut Juang dkk. (2016: 6), situasi tersebut merupakan bagian dari proses kontrol sosial yang dilakukan pemerintah. Pada saat itu, perhatian masyarakat Indonesia tertuju pada pergolakan, penjarahan, dan tindak kekerasan yang terjadi di pusat, sebagaimana dinyatakan Sunarlan (2000) dalam Saputra (2001: 263). Berbeda dengan di Jakarta, suasana di Kabupaten Banyuwangi sangat mencekam. Ada pasukan berpakaian serba hitam 'ninja' yang bertugas mengeksekusi para dukun santet, namun yang menjadi korban adalah dukun pengobatan, pawang hujan, dan pemuka agama. Menurut Saputra (2001: 263) dengan mengutip Kusnadi (1993), ada salah pengertian dalam pelabelan atau stigma atas 'dukun santet'. Sejak dekade 1950an, kata 'santet' mengalami perluasan makna sehingga selalu diidentikkan dengan ilmu hitam, padahal yang berkaitan dengan ilmu hitam adalah sihir. Seseorang akan disebut 'dukun santet' karena disinyalir mempraktikkan ilmu hitam (Setiawan, 2019).

Peristiwa pembunuhan terhadap 'dukun santet' ini ternyata pernah juga terjadi pada tahun 1991 dan 1996 (Teguh, 2018). Agar tragedi seperti ini tidak terjadi lagi, Setiawan (2019), dengan mengutip Brown (1999), mengungkapkan bahwa Bupati Banyuwangi pada tanggal 6 Februari 1998 mengeluarkan instruksi pada seluruh camat untuk mendata paranormal, dukun pengobatan, maupun tukang sihir. Namun rupanya daftar tersebut bocor dan berubah menjadi daftar target pembunuhan yang terjadi tahun 1998. Tidak ada kelanjutan dari upaya mengungkap kasus pelanggaran HAM oleh pemerintah terhadap korban dan keluarganya ini. Juang dkk (2016: 7) berargumentasi bahwa peristiwa ini juga merupakan dampak dari adanya provokasi terhadap dua kelompok muslim terbesar di Jawa Timur yaitu Nahdlatul Ulama dan Muhammadiyah. Korban pembantaian ini, menurut Manan \& Wardhana (2001) yang dikutip Saputra (2001: 263) diperkirakan mencapai jumlah 174 orang, sedangkan Komnas HAM mencatat korban berjumlah 309 orang (Setiawan, 2019).

'Sampur merah' yang menjadi bagian dari judul novel adalah selendang, benda yang tidak terpisahkan dari dunia gandrung, yang juga merupakan latar sosial buku tersebut. Gandrung, menurut Sumarno (2002: 306) adalah jenis tari pergaulan yang bersifat hiburan dan berperan dalam kehidupan masyarakat, terutama dalam pelbagai upacara di Banyuwangi, yang kerap dianggap memiliki kelindan dengan dunia santet dan Partai Komunis Indonesia (Dewi, 2017: 2). Para penari gandrung diyakini membekali diri dengan magi pengasihan yang membuat para penonton [laki-laki] terpikat. Dalam konteks sejarah, gandrung muncul ketika Belanda masuk ke Banyuwangi dan kekuasaan Kerajaan Blambangan sedang melemah. Oleh karena itu, menurut Dewi (2017: 16), masyarakat Banyuwangi mengadakan perlawanan melalui tari gandrung dan lagu-lagu yang dinyanyikan.

Dengan latar belakang kisah dan sejarah seperti itulah, novel Perempuan Bersampur Merah ditampilkan oleh Intan Andaru. Sebagai penyintas, tokoh Sari digambarkan memiliki karakter yang kuat sekaligus rentan dalam usahanya menelusuri 
kembali pengalaman pahit di masa kecilnya. la terindikasi melakukan perlawanan terhadap stigma yang melekat pada ayahnya dan juga dirinya dan juga trauma yang ia hadapi sejak kecil.

Stigma, menurut Goffman dalam Larson \& Corrigan (2008) yang dikutip Varamitha, Akbar, dan Erlyani (2014), adalah suatu atribut yang mendiskreditkan seseorang sebagai manusia yang 'tidak sama seutuhnya' dengan manusia normal dan biasanya merujuk pada hal yang negatif. Definisi lanjutan dari Elliot (dalam Brohan, Slade, Clement, dan Thornicroft, 2010), stigma merupakan bentuk penyimpangan penilaian suatu kelompok masyarakat terhadap individu yang salah dalam interaksi sosial. Stigmatisasi terbentuk melalui proses sosial-kognitif yaitu isyarat, stereotip, prasangka, dan diskriminasi.

Selain stigma, tema utama yang muncul dalam novel Perempuan Bersampur Merah adalah trauma. Sebagaimana diargumentasikan Caruth (1995), trauma dapat muncul dalam diri seseorang karena mengalami kejadian traumatis yang membuat jiwanya terguncang serta sulit menerima kejadian buruk itu sebagai bagian dari hidupnya. Trauma dipahami bukan sebagai luka fisik melainkan cedera pada pikiran atau seseorang, sebagaimana dinyatakan Rebers (1995) dan Erikson (1989) yang dikutip Deborah (2018: 124). Peristiwa yang menimbulkan trauma, menurut Mendatu (2010: 22) sangat beragam jenisnya. Berdasarkan keterlibatan individu dalam peristiwa traumatik, ada tiga jenis trauma yaitu impersonal, interpersonal, dan kelekatan.

Dalam menghadapi stigma dan trauma, Sari dan beberapa tokoh perempuan lainnya terindikasi bersikap resilien. Resiliensi, menurut Glicken (2006) yang dikutip Deborah (2018: 123-124), adalah kemampuan individu untuk menahan dan bangkit kembali (bounce back) dari tantangan hidup yang mengganggunya. Dengan kata lain, individu yang mengalami resiliensi telah mengalami suatu kejadian yang dianggap traumatis oleh orang lain, namun dapat individu itu dapat bertahan menghadapi kondisi tersebut. Resiliensi juga berarti kemampuan untuk berkembang, menjadi dewasa, dan meningkatkan kompetensi diri dalam ruang lingkup yang tidak menguntungkan dirinya.

Schoon (2006) mengargumentasikan konsep resiliensi sebagai proses dinamika yang dialami individu dengan menunjukkan fungsi adaptif dalam menghadapi permasalahan yang dihadapi. Konteks permasalahan yang sering dihadapi individu yang resilien, menurut Schoon (2006), adalah (a) datang dari keluarga yang memiliki resiko tinggi seperti keluarga dari tingkat sosial ekonomi rendah, (b) memiliki riwayat penganiayaan, (c) memiliki kekurangan fisik atau terkena penyakit kronis, (d) memiliki pengalaman yang stressful, dan (e) mengalami trauma.

Selain novel Perempuan Bersampur Merah dan film Misteri Banyuwangi (1998) yang disutradarai oleh Walmer Sitohang, menurut AM (2019), peristiwa pembunuhan dukun santet di Banyuwangi pernah diangkat Langit Kresna Hariadi dalam novelnya Kiamat Para Dukun (2004). Karya tersebut telah dikaji oleh Prastica (2016) yang merumuskan simpulan bahwa penulisan novel itu didasari oleh keprihatinan pengarang terhadap masyarakat setempat yang sangat percaya pada dukun, lebih daripada kepercayaan mereka pada dokter. Sebagai akibatnya, banyak bermunculan dukun palsu yang bermotif ekonomi semata. Terjadi pula fitnah antardukun untuk saling menonjolkan diri dan menjatuhkan lawan dalam upaya mereka mencari pelanggan.

Beberapa penelitian terdahulu telah menggunakan novel Perempuan Bersampur Merah karya Intan Andaru. Pertama, penelitian yang dilakukan oleh Fachrudin (2020) yang membahas konflik batin, yang meliputi fitnah, kekerasan, pengkhianatan, kemiskinan, cemburu, serta percintaan. Penelitian ini menggunakan pendekatan psikologi sastra dengan teori Kurt Lewin. Hasil penelitian mengungkap adanya empat puluh data konflik batin, yang meliputi konflik mendekat-mendekat (approach-approach conflict), konflik menjauh-menjauh (avoidance-avoidance conflict), dan konflik mendekat-menjauh (approach-avoidance conflict). 
Penelitian lain dengan objek penelitian yang sama dilakukan oleh Nurdayana (2019), yang berfokus pada pertentangan kelas sosial modern dan non modern, serta bentuk stratifikasi sosial pada masyarakat Banyuwangi dan menganalisis pandangan dunia pengarang. Untuk mengupasnya, penelitian tersebut menggunakan teori strukturalisme genetik Goldman. Hasil penelitian mengungkapkan adanya pertentangan sosial dalam masyarakat antara kelompok modern dan non modern. Selain itu ditemukan tiga bentuk stratifikasi sosial yaitu berdasarkan kekuasaan, kehormatan, dan tingkat pendidikan. Pandangan dunia pengarang mengarah pada isu lokal tentang polemik keberadaan dukun santet.

Penelitian dengan pendekatan sosiologi sastra pada novel Perempuan Bersampur Merah dilakukan oleh Ernawati (2020) dan Mawarni (2020). Ernawati (2020) membahas perjuangan seorang anak perempuan untuk mengungkap teka-teki peristiwa pembunuhan pada ayahnya dalam tragedi Banyuwangi tahun 1988. Alur cerita yang digunakan campuran, latar tempat secara umum di Banyuwangi, dengan latar waktu antara tahun 1994-2012. Buku tersebut dinilai dapat digunakan sebagai bahan ajar sastra di SMA karena memuat nilai sosial seperti kasih sayang, tanggung jawab, dan keserasian hidup. Sedangkan Mawarni (2020) menyimpulkan bahwa bentuk konflik sosial dalam novel Perempuan Bersampur Merah meliputi konflik internal dan eksternal. Penyebab konflik adalah perbedaan keinginan antara protagonis dengan masyarakat serta pola interaksi yang menimbulkan distorsi berupa hasutan. Dampak dari konflik adalah perubahan kepribadian, rusaknya norma sosial yang menimbulkan pertikaian dan pembunuhan, dan terjadinya perpecahan dalam masyarakat.

Dari paparan mengenai penelitian terdahulu ini, dapat diketahui bahwa pembahasan mengenai resiliensi perempuan terhadap stigma dan trauma terhadap novel Perempuan Bersampur Merah dengan pendekatan psikologi sastra belum pernah dilakukan. Oleh karena itu, penelitian ini memiliki peluang untuk dilakukan dan diharapkan dapat memperkaya wawasan pembaca mengenai peristiwa sejarah yang ditangkap dan dimaknai oleh karya fiksi. Untuk membatasi wilayah kajian, maka permasalahan penelitian ini berfokus pada analisis resiliensi perempuan terhadap stigma dan trauma, di dalam novel Perempuan Bersampur Merah karya Intan Andaru.

\section{Metode Penelitian}

Objek penelitian ini adalah novel karya Intan Andaru yang berjudul Perempuan Bersampur Merah, terbitan PT. Gramedia Pustaka Utama pada tahun 2019. Kajian terhadap novel tersebut dilakukan dengan pendekatan psikologi sastra, yaitu telaah karya sastra yang dapat mencerminkan proses dan aktivitas kejiwaan (Minderop, 2013: $54)$.

Data berupa kata, frasa, dan kalimat yang relevan dengan tujuan penelitian dikumpulkan dengan melalui metode studi pustaka, dengan langkah-langkah: dibaca, ditandai, dicatat, dan dikategorisasi. Selanjutnya, data dianalisis dengan teknik analisis isi, yaitu menjabarkan temuan dan memberi ulasan sebagai penjelasan dengan dilandasi teori-teori yang relevan. Kerangka teoretis yang menjadi landasan kajian ini adalah teori tentang stigma dari Goffman dan Elliot, trauma dari Caruth, Rebers, dan Erikson, serta resiliensi dari Glicken dan Schoon.

\section{Hasil dan Pembahasan}

\section{Struktur Cerita dalam Novel Perempuan Bersampur Merah}

Novel Perempuan Bersampur Merah terdiri dari 28 bab, yang diawali dengan prolog dan ditutup dengan epilog. Perguliran waktu ditunjukkan dengan penanda tahun yang tidak urut. Perspektif penceritaan datang dari tokoh Ayu/ Sari yang menggunakan gaya akuan. la adalah seorang anak perempuan yang diperkirakan lahir tahun 1989. Kisah dimulai dari saat dirinya masih balita berusia 4 tahun, anak kecil berusia 7-10 
tahun, remaja awal berusia 12-15 tahun, dan dewasa berusia 19-21 tahun. Dalam durasi progresif, cerita berlangsung selama 18 tahun, dari tahun 1994 hingga 2012.

Alur acak dan tidak kronologis yang digunakan dalam narasi mengindikasikan karakter narator-tokoh yang spontan dan lugu. Sebagai Ayu maupun Sari, narator selalu bercerita secara jujur dan tidak terkontaminasi oleh hal-hal besar di luar dirinya, terlebih lagi yang bersifat politik. la menyampaikan sesuai dengan yang ia lihat dan dengar. Banyak hal yang tidak ia pahami, terutama ketika melihat orang-orang yang sangat dikenalnya mengarak, memukuli, dan membantai ayahnya yang dianggap sebagai dukun santet di muka umum.

Malam itu, kulihat dengan mata kepalaku sendiri, mereka menyeret Bapakmengambil Bapak dari kami. Bapak yang melolong meminta tolong tak digubris sama sekali. Bahkan para tetangga dekatku yang terbangun karena keramaian malam itu tak dapat melakukan apa-apa selain memandangi kami dan menutup mulutnya. (Andaru, 2019: 65)

Sifat penceritaan narator-tokoh ini menjadi sangat terbatas, karena ia tidak bersifat omniscient 'maha tahu'. Narasinya menjadi subjektif, karena Sari tidak selalu paham penyebab dari setiap peristiwa yang terjadi dalam hidupnya, dan informasi hanya ia peroleh dari keterangan tokoh-tokoh lain yang juga diragukan kebenarannya. Kesan yang ditimbulkan dari teknik penceritaan semacam ini adalah realistis dan mengindikasikan masih banyak pertanyaan yang tidak mendapatkan jawabannya. Untuk menemukan jawaban itulah, Ayu/ Sari sebagai narator melakukan penyelidikan dengan bantuan kedua sahabatnya, Ahmad dan Rama.

Sari tidak benar-benar tahu apakah ayahnya seorang dukun santet atau bukan. Namun sepengetahuannya, yang dilakukan oleh ayahnya adalah menyuwuk atau mengobati dengan doa-doa, jampi-jampi, atau mantera (hal. 52, 134). Demikian pula dengan Pak Muhidin yang justru sering membantu orang yang meminta bantuannya sebagai pawang hujan (hal. 61). Ayu/ Sari sangat yakin bila ayahnya tidak seperti yang dituduhkan masyarakat, ayahnya tidak pernah menyakiti orang lain (hal. 71). Sari tahu, karena ia selalu berada di sisi ayahnya. Namun tuduhan ayah Rama bahwa ayah Sari adalah dukun santet yang menyebabkan kematian beberapa warga desa tetap menggoncangkan hati anak perempuan itu (hal. 200).

Keyakinan ayah Rama pun ternyata tidak unik. Masyarakat kampung pada umumnya juga percaya bahwa semua dukun, atau orang-orang yang memiliki 'ilmu', memiliki kemampuan untuk mengganggu dan menyakiti orang lain. Mereka percaya bahwa penyakit datang karena dikirim (hal. 33, 35, 37, 50), namun sebaliknya, mereka juga akan meminta bantuan pawang untuk menahan hujan saat akan mengadakan pesta (hal. 46). Keyakinan pada kekuatan yang ada di luar dunia manusia ini juga ditunjukkan dengan kepercayaan pada kekuatan jenglot (hal. 47), atau kepercayaan bahwa anak kecil tidak boleh berada di luar rumah saat surup karena akan diikuti makhluk halus yang disebut sawan (hal. 49-50). Orang-orang juga masih menggunakan kembang setaman untuk selamatan weton dan berziarah untuk memberi 'makan' pada leluhur (hal. 61). Anak yang sering sakit pun dianjurkan mengganti nama (hal.94). Sebagian dari mereka juga masih melakukan puasa weton atau puasa di hari lahir sesuai pasaran/ perhitungan tanggal Jawa (hal. 98). Beberapa orang bahkan masih mempercayai tafsir mimpi sebagai materi untuk memasang togel (hal. 108). Di wilayah Banyuwangi, beberapa tradisi lama masih dilakukan, seperti tradisi koloan saat sunatan (hal. 39) dan juga geredoan, yaitu tradisi di beberapa kampung Using saat peringatan Maulid Nabi yang bersamaan dengan ajang cari jodoh untuk para lajang (hal. 172).

Dengan latar tempat, waktu, dan sosial seperti itulah cerita dikonstruksi dengan berpusat pada pergerakan yang dilakukan Ayu/ Sari sebagai tokoh utama. Dari seluruh 
pembahasan mengenai struktur cerita pada novel Perempuan Bersampur Merah ini, terungkap bahwa seluruh elemen naratif mendukung pada isu yang akan dibincangkan pada bagian selanjutnya.

\section{Perempuan Bersampur Merah: Narasi tentang Stigma}

Masyarakat Banyuwangi dikenal terbiasa mendatangi dukun untuk banyak kejadian penting, seperti selamatan pindah rumah, membangun rumah, menyongsong panen, khitan, atau pernikahan. Kepercayaan warga pada hal-hal gaib terungkap sepanjang kisah yang dinarasikan Sari, yang menegaskan adanya berbagai keyakinan mereka pada dunia supranatural.Santet yang awalnya berarti ilmu gaib untuk tujuan pengasihan berubah menjadi cenderung bertujuan mengirim malapetaka kepada orang lain sebagaimana tenung yang membahayakan. Kata orang-orang, bila kita melihat cahaya putih yang berkelebat di langit, apalagi jika cahaya itu memancarkan warnawarna, maka kita dianggap telah melihat wujud santet yang lewat (hal. 147). Dalam hal ini, dapat dinyatakan bahwa ilmu santet telah distigmatisasi.

Mereka bisa memasukkan paku, rambut, besi, silet, kalajengking, kelabang, beling, dan apa pun yang mengerikan pada tubuh seseorang. Masyarakat Using sendiri menyebut ilmu hitam seperti itu sebagai ilmu sihir (Andaru, 2019: 76).

Peristiwa kematian Pak Muhidun membuat ayah Sari merasa waswas dengan nasibnya, tapi ia tidak ingin melarikan diri karena tindakan itu akan memperkuat stigma yang melekat padanya sebagai dukun santet. Stigma dukun santet dapat diasumsikan sebagai 'pembangkang' dan 'manusia pendosa', dan sebaliknya, para pembunuh itu adalah 'utusan Gusti Allah' dan 'malaikat' (hal. 71). Stigma itu semakin menguat dengan ditemukannya daftar nama orang yang diduga sebagai dukun santet. Namanama mereka, menurut Sari, didapatkan dari radiogram yang dikirim pemerintah.

Kami tak mengerti apa itu radiogram sebab kami tak punya radiogram dan tak pernah melihat seperti apa benda itu. [...] Melalui radiogram itu, pemerintah menyuruh para aparat kampung untuk mencatat nama-nama warga yang terduga dukun santet agar diamankan. Sayangnya, nama-nama itu justru tersebar ke masyarakat luas dan membuat warga lebih mudah mencari siapa saja yang namanya tercatat sebagai dukun santet lantas melakukan penghakiman atas inisiatif mereka (Andaru, 2019: 77).

Stigma sebagai anak dukun santet melekat pada Ayu/ Sari sehingga di kemudian hari para tetangga masih bicara "Jangan menikahinya, ia anak dukun santet." (hal. 9). Setiap hari weton Sari, ayahnya biasa menyediakan jajanan pasar yang harus dibagikan pada anak-anak tetangga. Dulu mereka menyenangi itu, namun setelah tragedi, hanya sedikit anak yang mau menerima makanan dari selamatan Sari (hal. 99).

Kurasa orang-orang dewasa terlalu sulit dipahami. Mereka membuat aturanaturan yang kadang tak adil sama sekali. Bagaimana bisa, kami yang lahir secara utuh membawa badan dan pikiran kami sendiri selalu dinilai sebagai jelmaan orang tua kami. (Andaru, 2019: 154)

Hingga Sari dewasa dan menjalin hubungan dengan Rama, ayah laki-laki itu masih belum dapat menerimanya, karena berita tentang ayah Sari yang dituduh dukun santet tidak akan pernah hilang. Sari yakin hubungannya dengan Rama selamanya tidak akan direstui (hal. 173). 
Para dukun santet itu memang harus dibunuh, atau bila tidak, satu per satu warga kampung yang tak bersalah akan menjadi korban dari ilmunya. [...] Bapak ndak salah. Bapak hanya sedang menyelamatkan kampung." (Andaru, 2019: 2000)

Seperti santet, penari gandrung juga memiliki stigma tidak baik. Meskipun Mak Rebyak sudah berusaha memperbaiki citra buruk itu, kehamilan Mbak Nena merusaknya kembali. Selain pakaiannya yang dianggap cukup seksi dan dapat mengandung berahi, para penari gandrung memang sering disangkutpautkan dengan praktik ilmu santet pengasihan yang berujung pada kemaksiatan (hal. 132).

Berita miring tentang gandrung memang sering mencuat di kalangan warga yang mengaku mendalami agama. Mereka sempat menolak keberadaan tari gandrung, bahkan sempat memberi wacana agar patung-patung gandrung di kotaku dihancurkan. Gandrung dikatakan hanya membawa maksiat bagi warga. Para penari berpakaian seksi, tidak sopan, para penonton gandrung mabukmabukan, dan terjadilah hal-hal yang ditentang agama. (Andaru, 2019: 119)

Penari gandrung dipercaya menanam susuk yang ditanam pada bagian tubuh tertentu atau pun sabuk mangir yang diisi pada jimat yang ia miliki (hal. 125). Gandrung juga dianggap sering menggunakan pelet untuk menarik orang lain dengan mantra.

Ada pula stigma perempuan hamil di luar nikah yang melekat pada Mbak Nena, orang tidak segan mengata-ngatainya (hal. 122). Sebaliknya, tidak ada sedikitpun pembahasan mengenai laki-laki yang telah menghamilinya. Sementara itu, anaknya dapat dipastikan menerima pandangan negatif. Oleh karena itulah, untuk menghindari stigma buruk pada anak Mbak Nena yang lahir di luar nikah, nenek dan kakek bersedia mengakui bayi itu sebagai anak. Dengan demikian, Mbak Nena akan berperan sebagai kakak anak itu (hal. 141). Stigma yang terancam akan melekat padanya sebagai 'anak haram' dicoba dihindarkan demi masa depan anak itu kelak.

Stigma lain melekat pada Sari sebagai perempuan dewasa yang belum menikah, ia dianggap adalah perawan tua, yang tidak laku 'dijual'. Di usianya yang baru dua puluhan, Sari juga mulai dikuatirkan oleh ibunya.

lbu ingin anaknya segera menikah. Orang-orang kampung mulai bergunjing tentang aku. Padahal aku masih cukup muda. Baru saja kepala dua. Tapi di kampung kecil seperti ini, seorang perempuan yang sudah tak sekolah, berapa pun usianya, sudah dianggap matang untuk menikah. Apalagi lbu yang begitu percaya dengan keyakinan turun-menurun itu- tentang larangan menolak lamaran seseorang, keharusan menyegerakan pernikahan, dan ketakutan menjadi perawan tua. (Andaru, 2019: 174-175)

Stigma juga melekat pada anak dan keturunan dari anggota partai terlarang seperti yang dialami Ahmad dan keluarganya. la tidak dapat menjadi tentara karena kakek ayahnya adalah mantan aktivis di masa lalu (hal. 151).

"Mbahku kan dengar beberapa temannya dibunuh dengan keji, ada yang digorok, dijerat, dan lain-lain. pokoknya seram. Mbahku sempat melihat sendiri tubuh teman-temannya dipotong kayak nyacah daging nangka muda, mayatnya digeletakkan gitu saja di pos kamling di kampung. [...] Mbahku ketakutan. [...] mereka nemu mayat Mbahku tergantung di pintu kamar. Mbah bunuh diri tanpa pesan apa-apa." 
$[\ldots]$

"Karena nama Mbah, bapakku dan adik-adiknya sulit cari kerja. Bukan hanya aku, Sar. Bapakku juga punya cita-cita jadi tentara. Jadi penyelamat negara. Keren sekali rasanya. Tapi cita-cita itu tak pernah kami kejar.” (Andaru, 2019: 152-153)

Seluruh stigma yang terungkap di dalam novel Perempuan Bersampur Merah ini berkonotasi negatif dan bersifat merugikan orang-orang yang dikenainya. Stigma yang ditemukan di antaranya adalah (1) stigma pada dukun santet yang berakibat pada pembunuhan, (2) stigma pada anak dukun santet yang berakibat pada pengucilan, (3) stigma pada penari gandrung yang berakibat pada minimnya permintaan 'manggung', (4) stigma pada perempuan hamil dan anak yang lahir di luar nikah yang berakibat pada pengucilan, (5) stigma pada perempuan dewasa yang belum menikah yang berakibat pada pergunjingan, dan (6) stigma pada keturunan anggota partai terlarang yang berakibat pada hambatan dalam mencari pekerjaan.

\section{Resiliensi Perempuan dalam Menghadapi Trauma}

Melalui Pratiwi \& Hirmaningsih (2016: 69), Marlia (2010) mengungkapkan bahwa meskipun menghadapi permasalahan berat dalam hidupnya, banyak perempuan yang mampu terus mempertahankan hidupnya dan menyesuaikan diri dengan keadaannya. Kemampuan untuk bangkit dari keterpurukan ini disebut resiliensi (Siebert, 2005).

Bentuk trauma yang terungkap dialami Ayu/ Sari adalah bayangan tentang suasana saat kejadian, yang membuatnya tidak bisa berpikir tenang, takut ke luar rumah, takut gelap, dan takut saat malam datang (hal. 71). la juga merasa tercekik mengingat guratan di leher ayahnya yang membuatnya sering merasa sesak saat bernapas (hal. 72).

Di kepalaku, masih tergambar jelas suasana malam itu. Kepalan tangan mereka, tatapan bengis, dan suara tinggi mereka. Apa yang tampak malam itu begitu membuatku yakin bahwa mereka memiliki hati yang teramat jahat. Tak ada orang baik yang memandang bapakku dengan tatapan macam itu, tak ada orang baik yang meneriaki bapakku seperti itu. (Andaru, 2019: 42)

Bentuk pertama dari resiliensi yang dilakukan Ayu/ Sari adalah upaya menjauhi hal-hal yang tidak disukainya yang membuatnya ingat pada traumanya. la juga ingin menangkap orang-orang yang membunuh ayahnya (hal. 182).

Aku sungguh tak ingin ke mana-mana. [...] aku malas melihat jalanan. Aku malas merasakan udara malam. Aku malas mendengar bunyi langkah kaki orang. Aku malas menangkap tatapan orang. Tiap kali aku melihat ke luar rumah, aku sungguh masih dapat merasakan kejadian malam itu. Ingatanku tentang gerombolan orang yang mengepung rumah. (Andaru, 2019: 70)

Selanjutnya, Ayu mencatat nama-nama pelaku itu dalam selembar kertas (hal. 71). la juga mencoba mengabaikan bayangan buruk tentang ayahnya (hal. 73). Ayu mengingat sosok ayahnya melalui sepatu boot dan niat untuk memperbesar foto KTP ayahnya suatu hari nanti (hal. 87). Karena sakit-sakitan, Ayu berganti nama menjadi Sari pada umur 10 tahun. Sari kemudian belajar menari gandrung di tempat Mak Rebyak, demi mendapatkan informasi tentang Sotar, orang yang terlibat dalam pembunuhan ayahnya. Di umurnya yang masih sangat muda, Sari bekerja keras untuk mendapatkan uang (hal. 111). 
[...] dan musik mulai dilantunkan, entah dari mana, aku mampu merasakan tubuhku menjadi amat ringan seolah terbang melayang sampai-sampai aku lupa akan ingatan tentang jenazah Bapak dengan guratan di lehernya yang seing membayang itu. Perasaan mencekik tiap kali aku ingat di masa lalu itu, pelan-pelan menghilang dengan sendirinya. (Andaru, 2019: 113)

Sari berlatih tari gandrung baik di sanggar maupun di rumah dengan bimbingan Mbak Nena sehingga timnya meraih juara II pada festival di Surabaya. Merasa telah mendapat kepercayaan dari Mak Rebyak, Sari berani mengajukan pertanyaan sebagai bagian dari penyelidikannya tentang Sotar.

[...] setidaknya, aku sudah mulai mengerti benang merahnya -nama-nama yang tercatat di lembar kertasku. Orang-orang yang bersemangat membunuh Bapak malam itu adalah mereka yang pernah atau sedang memiliki kerabat yang sakit dan yang mereka percayai akibat kiriman yang disebut santet. (Andaru, 2019: 135)

Mak Rebyak, yang mengetahui trauma dan dendam yang dirasakan oleh Sari, menasihatinya untuk melupakan masa lalu karena dapat melukai diri sendiri (hal. 135). Pada akhirnya, Sari menyadari bahwa ia bukan satu-satunya yang paling menderita, karena tanpa ia ketahui orang-orang di sekitarnya, seperti Ahmad, pun memiliki masalah yang juga berat untuk dihadapi.

Saat Sari dihadapkan pada acara perjodohan dan Ahmad mendekatinya, Sari menolak menikah hanya karena tidak mau digunjing sebagai perawan tua. Hatinya sudah memilih Rama (hal. 178). Demi menuntaskan rasa ingin tahuannya tentang penyelesaian dari tragedi pembunuhan ayahnya dan banyak orang lainnya, Sari hadir di pertemuan keluarga korban Banyuwangi 1998 (hal. 183). Beberapa keluarga korban mengaku belum ikhlas dan ingin kasus ini diusut tuntas, beberapa lagi sudah ikhlas dan tidak ingin membahasnya, beberapa lagi meminta pemerintah memberi santunan untuk keluarga yang ditinggalkan.

Toh aku sudah tak ingin dan tak akan meminta apa-apa pada mereka. Entah siapa yang bersalah tentang kasus Bapak, lebih baik aku tak peduli lagi. Bila aku mencari, yang kutemukan hanya sakit hati. Aku sungguh tak mau tahu mengenai mereka lagi. Aku tak ingin memikirkannya lagi. Aku cuma ingin lupa. Hidup tenang sebagaimana Paman dan keluarganya. (Andaru, 2019: 203)

Karena ingin melupakan ingatan kelam tentang pembunuhan ayahnya, Sari pun memilih untuk pergi dan berdamai dengan masa lalu sebagaimana yang dilakukan pamannya (hal. 203). Rama, yang ia cintai dan ia tunggu, ternyata tidak benar-benar mencintainya, hanya menyayangi dan mengasihani Sari sebagai sahabat.

Sepeninggal Bapak, Ibu berusaha melanjutkan hidup demi anaknya. Perempuan ini pun memelihara kenangan tentang sosok suaminya dengan niat membesarkan foto itu suatu saat nanti jika Sari sudah bekerja (hal. 87). Ibu juga menjalin hubungan baik dengan Paman sekeluarga (hal. 90).

[...] suara Ibu sungguh menyadarkanku bahwa sedihku akan kehilangan Bapak bukanlah apa-apa dibanding perasaan lbu. Terlebih setelah tahun-tahun berikutnya, aku mulai mengerti bahwa kehilangan Bapak telah memaksa Ibu menjadi dua orang sekaligus -menjadi ibu dan ayah untukku. Ibu harus memasak, mencuci, mengurusku, mengurus ayam-ayam kami. [...] Ibu harus bangun dini hari berkutat dengan adonan jajan dan menjualnya ke pasar hingga siang untuk mencari nafkah. (Andaru, 2019: 96) 
Ibu membesarkan Sari dan mendukung saat putrinya memiliki rencana melanjutkan studi ke Bogor agar dapat diterima oleh keluarga Rama bila ia bergelar sarjana. Pada akhirnya, seperti paman, lbu juga kecewa pada kampung itu, yang mengingatkan dirinya pada suaminya dan para pembunuh yang tinggal di sekitarnya. Ibu dan Sari pun memutuskan untuk pergi ke tempat paman (hal. 202).

Bukan hanya lbu dan Ayu/ Sari yang terluka, paman, adik ayahnya, juga sakit hati pada kampung itu (hal. 9). Saat peristiwa pembantaian, paman berusaha melindungi lbu dan Ayu.

Terlalu sakit bila Paman tetap tinggal di kampung -yang sebagian penduduknya telah ikut membunuh kakak kandungnya sendiri. Paman bilang akan sulit hidup di kampung yang telanjur mengira kami keluarga dukun santet. Lebih baik tinggal di suatu tempat -yang tak seorang pun mengetahui kejadian yang menimpa kami. (Andaru, 2019: 88)

Paman, bibi, dan Mbak Rohayah pun terpaksa pindah ke Ponorogo. Mereka mengalami masa-masa sulit sebagai pendatang dan tidak memiliki bekal memadai. Namun, berkat kerja keras paman dan bibi, mereka pun mendirikan rumah makan rujak cingur dan telah memiliki beberapa pegawai (hal. 9). Mereka sering menyempatkan menulis surat dan mengirim uang pada lbu (hal. 88).

Mak Rebyak disebut-sebut sebagai kekasih gelap Sotar, namun karena pernah dilabrak oleh istri sah laki-laki itu, Mak Rebyak pun memutuskan menjanda saja. la sudah dua kali bercerai dan sekali gagal menikah (hal. 112). Keluarganya masih percaya kalau tidak ada keturunan yang menjadi gandrung, maka akan ada keluarga yang sakit. Hal ini membuatnya kebingungan dalam mencari penerus.

Semua itu berhubungan sama nazar leluhur mereka di masa lalu. Nah sekarang, cuma Mak Rebyak yang jadi gandrung di keluarganya. Keluarga yang lain ndak ada yang berniat jadi gandrung. Mak Rebyak kebingungan soalnya ndak ada yang mau meneruskannya. Dia sering ngeluh sakit kepala karena masalah ini. (Andaru, 2019: 114)

Alasan Mak Rebyak bertahan menjadi penari gandrung adalah ketakutannya bila ada keluarganya yang sakit keras. Sementara anak-anaknya lebih memilih tinggal di kota. Namun, Mak Rebyak merasa gagal membangun citra gandrung bagi warga (hal. 119). la pun menunjuk Sari untuk menggantikan Mbak Nena sebagai pemimpin tim festival tari gandrung di Surabaya (hal. 123).

Setelah kemenangan timnya di festival tari, Mak Rebyak tampak merasa susah hati karena mendapat banyak undangan menari (hal. 130). la mencemaskan semakin langkanya orang yang mau menjadi gandrung karena proses belajarnya yang sulit dan stigma negatif yang masih terus melekat pada profesi itu. Untuk mengatasi permasalahannya, ia merekrut banyak penari baru yang muda, segar, dan cantik (hal. 205). Namun demikian, tetap saja sanggarnya tertinggal oleh sanggar-sanggar baru yang lebih kreatif dan kompetitif.

Mbak Nena adalah pelatih tari di sanggar Mak Rebyak, sudah memiliki pacar bernama Yudi. Mbak Nena sering kencan dengan pacarnya saat Mak Rebyak tidak ada di rumah (hal. 117), hingga membuatnya hamil (hal. 118). la pun pergi dari rumah dan dipecat dari sekolah tari.

"Setelah aku memberitahunya kalau aku hamil, Yudi ndak ada kabarnya. la ndak mau tahu tentang aku dan kehamilanku. la malah menuduhku dihamili 
lelaki lain. mau lapor polisi pun, ndak mungkin. Aku malah mempermalukan keluargaku." (Andaru, 2019: 119)

Mbak Nena tetap mengajar tari pada Sari (hal. 122). Setelah keluarga mau menerimanya kembali, ia pun melanjutkan sekolah di Sulawesi Utara. Di akhir cerita, ia datang ke rumah Sari yang telah berangkat ke Ponorogo, dan mendapatkan kembali sampur merahnya. Situasi ini menunjukkan bahwa Mbak Nena akan melakukan kegiatannya dulu, yaitu menjadi penari gandrung.

Dari pembahasan ini, terungkap bahwa para tokoh perempuan di dalam novel Perempuan Bersampur Merah, dengan caranya masing-masing, telah melakukan resiliensi untuk menghadapi stigma dan trauma.

\section{Kesimpulan}

Dekonstruksi atas tragedi pembantaian dukun santet dilakukan Intan Andaru dalam novel Perempuan Bersampur Merah dengan mengambil alih suara [anak] korban untuk diangkat ke permukaan sebagai bukti simpati dan keberpihakannya. Struktur narasi terungkap mendukung pembahasan mengenai tema resiliensi perempuan menghadapi stigma dan trauma.

Stigma yang ditemukan di antaranya adalah (1) stigma pada dukun santet yang berakibat pada pembunuhan, (2) stigma pada anak dukun santet yang berakibat pada pengucilan, (3) stigma pada penari gandrung yang berakibat pada minimnya permintaan 'manggung', (4) stigma pada perempuan hamil dan anak yang lahir di luar nikah yang berakibat pada pengucilan, (5) stigma pada perempuan dewasa yang belum menikah yang berakibat pada pergunjingan, dan (6) stigma pada keturunan anggota partai terlarang yang berakibat pada hambatan dalam bekerja.

Penulisan karya fiksi Perempuan Bersampur Merah dengan latar fakta sejarah peristiwa pembantaian [orang-orang yang dituduh] dukun santet merupakan bukti dari peran sastra dalam menyikapi peristiwa yang belum benar-benar selesai dan masih menyisakan beragam pertanyaan. Intan Andaru mengangkat kembali kisah tersebut setelah dua puluh tahun lebih berlalu tanpa ada penyelesaian secara hukum. Riset yang dilakukannya tidak mudah karena banyak sumber yang enggan terbuka.

\section{Daftar Pustaka}

AM, Kim A.G. (2019). Memahami Kembali Sebuah Tragedi Melalui Fiksi; Peristiwa Berdarah dalam Perempuan Bersampur Merah.

https://tatkala.co/2019/04/22/memahami-kembali-sebuah-tragedi-melalui-fiksiperistiwa-berdarah-dalam-perempuan-bersampur-merah/ Diakses tanggal 27 April 2020

Andaru, I. (2019). Perempuan Bersampur Merah. Jakarta: Gramedia Pustaka.

Brohan, E. Slade, M. Clement, S. \& Thornicroft, G. (2010). Experience of mental illness stigma, prejudice, and discrimination: a review of measures. BMC health services research. Vol. 10, No. 80.1-11.

Caruth, C. (1995). Trauma: Exploration in Memory. Baltimore: The John Hopkins University Press.

Deborah, S. dkk. (2018). Trauma dan Resiliensi pada Wanita Penyintas Kekerasan dalam Rumah Tangga. Jurnal IImiah Psikologi MANASA. Vol. 7, No. 2. 121-130.

Dewi, E.R. C. (2017). Kontroversi terhadap Penari Gandrung dalam Novel Kerudung Santet Gandrung karya Jasnan Singodimayan: Sebuah Kajian Sosiologi Sastra. https://susastra.fib.ui.ac.id/wp-content/uploads/81/2017/01/17-Makalah-Evi- 
Retno-Cristiyan-Dewi-Kontroversi-Terhadap-Penari-Gandrung-pro.pdf diakses tanggal 29 April 2020.

Ernawati, P. (2020). Nilai Sosial dalam Novel Perempuan Bersampur Merah Karya Intan Andaru: Tinjauan Sosiologi Sastra dan Relevansinya dengan Bahan Ajar di SMA. Skripsi. Program Studi Pendidikan Bahasa dan Sastra Indonesia, Fakultas Keguruan dan IImu Pendidikan, Universitas Muhammadiyah Surakarta.

Fachrudin, A. Y. (2020). Konflik Batin Tokoh Sari dalam Novel Perempuan Bersampur Merah Karya Intan Andaru (Kajian Psikologi Sastra Kurt Lewin). BAPALA. Vol. 7, No. 1. 1-9.

Sumarno. (2002). Peran Tari Gandrung Banyuwangi pada Masa Kini. Jakarta: Patra Widya.

Haris, M. \& Suwartini, I. (2019). Analisis Jenis Trauma Tokoh Utama dalam Novel Peter Karya Risa Saraswati Sebagai Alterntif Bahan Ajar Sastra di SMA. Komposisi. Tahnu 4, No. 2. 68-74.

Juang, R.P., Erviantono, T., \& Azhar, M.A. (2016). HAM dan Politik Kriminal Pasca Orde Baru (Konstruksi Pelanggaran HAM pada Kasus Pembantaian Dukun Santet) di Kabupaten Banyuwangi tahun 1998). E-Jurnal Politika. Vol. 1, No. 1. 18.

Mawarni, N. P. (2020). Konflik Sosial Tokoh Utama dalam Novel Perempuan Bersampur Merah Karya Intan Andaru (Kajian Sosiologi Sastra). Skripsi. Program Pendidikan Bahasa Indonesia, Fakultas Keguruan dan IImu Pendidikan, Universitas Muhammadiyah Malang.

Mendatu, A. (2010). Pemulihan Trauma. Yogyakarta: Jalasutra.

Minderop, A. (2013). Psikologi Sastra: Karya Sastra, Metode, Teori, dan Contoh Kasus. Jakarta: Yayasan Pustaka Obor Indonesia.

Nurdayana, I. (2019). Stratifikasi Kelas Sosial dalam Pandangan Dunia Pengarang Novel Wanita Bersampur Merah Karya Intan Andaru: Kajian Strukturalisme Genetik. Prosiding. SENASBASA (Seminar Nasional Bahasa dan Sastra). Vol. 3 No. 2. 409-417.

Prastica, R.E.R. (2016). Novel Kiamat Para Dukun Karya Langit Kresna Hariadi: Kajian Sosiologi Sastra, Nilai Pendidikan Karakter, dan Relevansinya terhadap Pembelajaran Bahasa Indonesia di SMA. Tesis. Prodi Pascasarjana Pendidikan Bahasa Indonesia. UNS.

Pratiwi, A.C. \& Hirmaningsih. (2016). Hubungan Coping dan Resiliensi pada Perempuan Kepala Rumah Tangga Miskin. Jurnal Psikologi. Vol. 12, No. 2, Desember 2016. 68-73.

Saputra, H.S.P. (2001). Tradisi Mantra Kelompok Using di Banyuwangi. Humaniora. Vol. XIII, No. 3. 260-267.

Schoon, I. (2006). Risk and Resilience Adaptations in Changing times. USA: Cambridge University Press.

Setiawan, R. (2019). Pembunuhan Dukun Santet 1998: Sistematis dan Terencana. https://tirto.id/pembunuhan-dukun-santet-1998-sistematis-dan-terencana-dePk diakses tanggal 27 April 2020

Siebert, A. (2005). The Resiliency Advantages. San Francisco: Berret-Koehler Publisher Inc. 
Teguh, I. (2018). Pembantaian Dukun Santet, Operasi Naga Hijau \& Teror kepada NU. https://tirto.id/pembantaian-dukun-santet-operasi-naga-hijau-teror-kepada-nucE5V diakses tanggal 27 April 2020

Varamitha, S. Akbar, S.N. \& Erlyani, N. (2014). Stigma Sosial pada Keluarga Miskin dari Pasien Gangguan Jiwa. Jurnal Ecopsy. Vol. 1, No. 3, Agustus 2014.

Wijayanto. (2019). Intan Andaru, Dokter Novelis Bagi Pengalaman. Gelisah Mendengar Pembantaian Dukun Santet.

https://radarsurabaya.jawapos.com/read/2019/01/16/114096/gelisah-mendengarpembantaian-dukun-santet diakses tanggal 27 April 2020. 